MICHAŁ GŁAŻEWSKI

Uniwersytet Pedagogiczny im. Komisji Edukacji Narodowej

Kraków
Forum Pedagogiczne

2018/1

Wpłynęło: 29.12.2017

Zatwierdzono do druku: 31.03 .2018 DOI: $10.21697 /$ fp.2018.1.11

\title{
EDUKACJA JAKO SYMULAKRUM
}

Streszczenie: Artykuł odnosi się do pojęcia symulakrum, metafory stworzonej przez Jeana Baudrillarda w pracy Symulakry i symulacja w 1981 roku, w której stara się on zbadać związki między rzeczywistością, symbolami i społeczeństwem, a w szczególności określić znaczenie i symbolikę - kultury i mediów, które są zaangażowane w konstruowanie rozumienia wspólnej egzystencji. Symulakry to kopie, przedstawiające rzeczy, kopie, które albo od początku nie miały oryginału, albo już pierwotny, źródłowy oryginał zatraciły. Symulacja jest imitacją działania rzeczywistego procesu lub systemu w czasie. Celem rozważań artykułu jest rozbiór zakresu semantycznego symulacyjnej funkcji edukacji w kontekście pytania o przydatność metafory symulakrum jako heurystycznego narzędzia tej analizy. Praca składa się z czterech części: 1. Edukacja - uściślenie terminologiczne; 2. Pytanie o symulacyjną funkcję edukacji; 3. Symulakrum jako heurystyczne narzędzie analizy edukacji; 4. Edukacja jako symulakrum hipermarketu.

Słowa kluczowe: edukacja, pedagogika, symulakrum, rzeczywistość, hiperrzeczywistość, symbole, kody, kultura, hipermarket.

Jean Baudrillard w swoim ponowoczesnym traktacie filozoficznym Symulakry i symulacja podjął próbę stworzenia radykalnej teorii interpretacji związków między rzeczywistością, symbolami i społeczeństwem, a w szczególności określenia znaczenia i symboliki - kodów kultury i mediów, które są zaangażowane w konstruowanie rozumienia wspólnej egzystencji. Dla potrzeb tej analizy stworzył pojęcie symulakrów - kopii, odwzorowań, replik, wtórników, imitujących, kopiujących, upodabniających się do rzeczy, które albo od początku nie miały oryginału, albo już ów pierwotny oryginał zupełnie zatraciły. Ich źródłem jest symulacja - imitacja istnienia czy działania rzeczywistego bytu lub procesu, bądź systemu w czasie, jako „sposób generowania - za pomocą modeli - rzeczywistości pozbawionej źródła i realności: hiperrzeczywistości” (Baudrillard 2005, s. 6). Baudrillard odróżnia jej trzy rodzaje: „symulację imitującą, która dominowała w klasycznym okresie renesansu, symulację produkcji w dobie industrialnej; wreszcie, symulację czasów współczesnych, w której decydującą rolę odgrywa kod” (Lechte 1999, s. 404)ํ․

1 Stąd także trzy porządki symulakrów: „symulakry naturalne, naturalistyczne, oparte na obrazie, naśladownictwie i podrabianiu, harmonijne, optymistyczne oraz zmierzające do przywrócenia, 
W poniższym wywodzie rozważana jest teza, że desygnatem tej trzeciej symulacji może być m.in. współczesna edukacja instytucjonalna. Czy metafora symulakrum może stanowić heurystyczne narzędzie rozbioru zakresu semantycznego symulacyjnej funkcji (po)nowoczesnej edukacji z jej „zawartą w kodzie zasadą reprodukcji" (Lechte 1999)?

\section{Edukacja - uściślenie terminologiczne}

Edukacja w niniejszym tekście jest rozumiana jako derywat łacińskiego educatio 'wychowuję, kształcę', wywiedzionego od bezokolicznika educere. Nań z kolei składa się przedrostek $e$-czyli 'wy'- i rdzeń -ducare pochodzący od ducere - 'wodzić, prowadzić. Stąd wynika polisemantyczny charakter pojęcia edukacji: w sensie "prowadzenia wzwyż - nazywanego w przedwojennej polskiej pedagogice psychagogią (Mirski 1936, s. 126), oraz siły „tego działania moralnego i umysłowego autorytetu wychowawców, jako ludzi najlepszych danego społeczeństwa i środowiska" (Kunowski 1993, s. 174-175), określanego analogicznie mianem agosu (gr. ago -'prowadzę'). Funkcje tegoż agosu S. Kunowski ujmuje jako: sanare, czyli opiekę wychowawców nad biosem wychowanka, a więc nad życiem i zdrowiem organizmu; oraz edocere (łac. edoceo - 'gruntownie nauczać, pouczać i uświadamiać); educere: ochronę wychowawczą nad działaniem etosu, czyli życia społecznego środowiska; educare: opiekę nad duchowością wychowanka i skierowanie jej do ideału; i w końcu funkcję initiare: wtajemniczenie i przygotowanie wychowanka do spotykania z losem (Kunowski 1993, s. 247-248).

Sens edukacji zasadza się zatem w rdzeniu czasowników: prowadzić, ciągnąć wzwyż, podnosić ku czemuś. Obecny jest doskonale w językach germańskich i romańskich - niemieckie erziehen czy großziehen, francuskie élever albo angielskie to bring up, bądź to raise.

Encyclopaedia Britannica definiuje edukację następująco: „Edukacja jest dyscypliną zajmującą się metodami nauczania i uczenia się w szkołach i w środowiskach typu szkolnego w przeciwieństwie do różnych nieformalnych i pozainstytucjonalnych form socjalizacji (nonformal and informel means of socialisation)" (hasło: Education). W szczególności podkreśla jednak kulturową funkcję edukacji: „jako transmisji wartości i nagromadzonej wiedzy społeczeństwa. W tym sensie stanowi ona ekwiwalent tego, co przedstawiciele nauk społecznych określają mianem

odtworzenia bądź ustanowienia w sposób idealny natury na wzór Boga; symulakry produktywne, produktywistyczne, oparte na energii, sile, zmaterializowane za pomocą maszyny w całym systemie produkcji - ich prometejskim celem jest globalizacja i bezustanna ekspansja, uwolnienie nieskończonej energii (pragnienie stanowi część energii wiążących się z tym porządkiem symulakrów); symulakry symulacji - oparte na informacji, modelu, cybernetycznej grze - całkowita operacjonalizacja, hiperrzeczywistość, celem ich jest uzyskanie całkowitej kontroli” (Baudrillard 2005, s. 149). 
socjalizacji lub inkulturacji ${ }^{2}$. Dzieci - czy to poczęte pośród członków plemion Nowej Gwinei, we Florencji czasu renesansu, czy w klasie średniej społeczności Manhattanu - rodzą się w obrębie pewnej kultury. Edukacja ma na celu poprowadzenie ich ku nauczeniu się kultury, modelując odpowiednio ich zachowania [...]" (Encyclopaedia Britannica, hasło Education, 2013).

I o tę funkcję edukacji wprowadzania do kultury, o wrastanie w etos społeczeństwa właśnie tutaj chodzi.

\section{Pytanie o symulacyjną funkcję edukacji}

Czy polska edukacja spełnia przywołaną powyżej funkcję transmitowania wartości, wiedzy, etosu społecznego, wprowadzania do kultury w sensie inkulturacji ${ }^{3}$, czy rzeczywiście „obiektywną funkcją praktyki pedagogicznej jest wdrażanie wychowanków do kultury, dokładniej do uczestnictwa w kulturze" (Kmita 1982, s. 22)? Tu właśnie rysuje się najwyraźniej linia sporu o status zmiany edukacyjnej i jej promocję: „Najbardziej podstawowe rozstrzygnięcia dotyczące systemów edukacyjnych dotyczą dopuszczanych przez nie zakresów owego uczestnictwa w kulturze, modeli pożądanych zachowań i kompetencji do działań" (Kmita, cyt. za: Witkowski 1988, s. 135).

W zasadzie istnieją dwa takie antagonistyczne modele promocji behawioru kulturowego, będące funkcją edukacji: model ewolucyjny (oparty na idei kontynuacji, wrastania w egzystencjalny fundament społeczeństwa) i model rewolucyjny (kreacji zmiany kulturowej przez negację, gwałtowną, radykalną przemianę, przełom) (Suchodolski 1981, s. 97-10o). Jednakże każdy z tych modeli jest w swojej skrajności wadliwy: rewolucyjna zmiana niesie ze sobą nieuchronnie „przerwanie tradycji” i „powstanie opozycji myślenia i działania” (Arendt 1991, s. 11) - tych najbardziej „elementarnych form realizacji człowieczeństwa” (Arendt 1991, s. 9). Odrzucenie tradycji, przerwanie ciągłości kulturowej „powoduje, że niemożliwe staje się widzenie świata w kategoriach przeszłości, teraźniejszości i przyszłości” (Arendt 1991, s. 11); człowiek trwa zanurzony w labilnym nurcie bytu swego tu i teraz, nie wiedząc, ba, nie pytając nawet, jaki jest kierunek tego nurtu ani w jakim miejscu sam się znajduje: „Bez tradycji, która wybiera i określa, która przechowuje, która wskazuje, gdzie są skarby i na czym polega ich wartość, wydaje się nie istnieć

$2 \mathrm{~W}$ oryginale: Education can be thought of as the transmission of the values and accumulated knowledge of a society. In this sense, it is equivalent to what social scientists term socialization or enculturation.

3 „Zgodnie z klasycznym ujęciem H. J. Herskovitsa inkulturacja jest uczeniem się kultury; procesem, w toku, w wyniku którego jednostka zyskuje kompetencję kulturową. „[...] W różnych fazach swojego życia jednostka asymiluje rozmaite składniki dorobku kulturowego. Zaczyna się od nabywania elementarnych nawyków motorycznych, higienicznych lub językowych, by dojść w wieku dojrzałym do skomplikowanego uczestnictwa w środowisku kulturowym" (Schulz, 1992, s. 20-21). 
świadoma ciągłość w czasie, a zatem nie ma ani przeszłości, ani przyszłości, tylko wieczna zmiana i biologiczny cykl życia” (Arendt 1961, s. 25).

Atrofia poczucia ciągłości istnienia, jaka musi być następstwem takiego animalnego „nagiego życia”, sprawia, że człowiek zostaje wyzuty z wartości wyższych, duchowych, „nieinstrumentalnych”, co czyni wątpliwym jego życie w ogóle (Głażewski 1996, s. 30). Staje się ono mnogością przypadkowych zdarzeń, nieplanowanych i nieprzewidywalnych, jałową „nieznośną lekkością bytu” ", powodowanego chaotycznym nie-porządkiem świata. Taka zmiana rewolucyjna, która „Wzywa do zaczynania wszystkiego od nowa” (Król 1994, s.13), do przerwania tradycji jako pamięci pokoleniowej i apoteozy nowego początku, stanowi źródło woli mocy wszelkich utopii, które - zrealizowane - nieuchronnie przekształcają się w koszmar dystopii ${ }^{5}$.

Klasycznym ujęciem tej dychotomii modeli promocji zmiany jest w polskiej pedagogice typologia Zygmunta Mysłakowskiego (Mysłakowski 1964): odróżnił on adaptacyjną i rekonstrukcyjną funkcję wychowania, traktując je jako dwa nieantynomiczne aspekty procesu. $Z$ jednej strony bowiem wychowanie przygotowuje dorastające pokolenie do przebudowy, przekształcania zastanej przez nie rzeczywistości, czyli społeczno-kulturowej rekonstrukcji; z drugiej zaś strony stanowi formę zachowania ciągłości kulturowej przez adaptację, akomodację, wrastanie młodej generacji w egzystencjalny fundament społeczeństwa ${ }^{6}$ : „każde

4 Nieznośna lekkość bytu - głośna powieść czeskiego pisarza Milana Kundery, opublikowana w 1984 roku we Francji. Kundera uważa, że egzystencja pozbawiona głębszych uczuć i doznań jest pozbawiona sensu: gdy życie codzienne jest zbyt lekkie, nie przynosi satysfakcji. Powtarzalność, przewidywalność, przyjemności bez smutków i wyzwań czynią człowieka kalekim, niepełnym, niespełnionym. Każdy ma tylko jedno życie do przeżycia, a to życie właściwie niezauważenie przecieka przez palce. Zarazem każde poszczególne życie wydaje się nieznaczące, a decyzje i wybory pojedynczego człowieka nie mają żadnego znaczenia: są nieznośnie lekkie, ponieważ indyferentne, nieróżnicujące istoty egzystencji. Ów brak znaczenia, ta lekkość staje się przez to nie do zniesienia. Amerykański reżyser, Philipe Kauffman, stworzył na podstawie książki film The Unbearable Lightness of Being (1988) - z Danielem Day-Lewisem i Juliette Binoche w rolach głównych. Obraz, mimo rezygnacji Kauffmana z wątków filozoficznych, odniósł wielki sukces w Ameryce i w Europie (za: Kronika filmu 1995, s. 528).

5 Utopia to filozoficzna idea omnipotencji - pierwotnie greckiego polis, potem różnych form państwa, niemająca szans urzeczywistnienia i nielicząca się z realnym stanem rzeczy i stosunków społecznych, wizja idealnego, egalitarnego społeczeństwa. Z tej idei wyrastały jednak konkretne programy przebudowy społecznej - i to wtedy utopia stawała się naprawdę straszna. $\mathrm{Z}$ reguły społeczeństwa dystopijne powstają $\mathrm{w}$ wyniku radykalnego przerwania ciągłości tradycji społeczno-kulturowej jako forma apoteozy Nowego Początku. Powszechnie głoszony jest pogląd, że dawny, tradycyjny styl życia, szczególnie instytucja rodziny i życie religijne, jest archaiczny, prymitywny i pozbawiony sensu. Dystopia - mroczna strona każdej utopii, pojawia się zawsze przy próbach realizacji utopii, lecz - jak pokazuje historia - jest tworem terminalnym (por. Głażewski 2010, s. 132-178).

6 Tak rozumiał funkcję społeczną wychowania np. Wilhelm Dilthey: „Społeczeństwo stanowi globalny regulator życia, uczuć i instynktów; nakłada ono na nieumiarkowane namiętności 
nowe pokolenie to nowa inwazja dzikusów” (Allen 1992, s. 20), „barbarzyńców” wymagających inkulturacji czy - szerzej - hominizacji jako procesu dojrzewania do pełni człowieczeństwa, „kształtowania się jednostki ludzkiej” (Allen 1992).

W edukacji problem może się pojawić, gdy w tym funkcjonalnym układzie adaptacja-rekonstrukcja wystąpi „niedobór zmiany” w sensie niedostatecznej kreacji „własnej koncepcji świata i siebie w tym świecie” (Obuchowski 1987, s. 19) lub „nadmiar zmiany, który [...] zakłóca stan otoczenia społecznego, będącego przedmiotem zabiegów oświecenia edukacyjnego" (Witkowski 1988, s. 147).

Ów dysfunkcyjny niedobór zmiany cechuje wychowanie w kulturze postfiguratywnej (kulturze „nieocenionych przodków”), które według znanej koncepcji antropologicznej Margaret Mead, przedstawicielki kierunku etnopsychologicznego, zwanego też konfiguracjonizmem lub „szkołą wzorców kulturowych”, czy „szkołą kultury i osobowości” (Olszewska-Dyoniziak 20oo, s. 33), polega na przekazywaniu wierzeń, norm zachowań i wzorców behawioru kulturowego przez starszych członków społeczności. Są oni przewodnikami, pośrednikami między przeszłością a współczesnością, „strażnikami tradycji”. Organizacja i funkcjonowanie społeczności opiera się na powielaniu, replikacji tej tradycji, a zachowanie sprzeczne z obyczajem może spowodować potępienie i wykluczenie z grupy. Pokolenia wstępujące przejmują wzorce kulturowe od pokoleń starszych, dojrzewanie implikuje imperatyw roli dorosłego członka społeczności. Taki konserwatywny, zachowawczy typ wychowania cechuje społeczeństwa tradycyjne, zamknięte małe społeczności, „społeczeństwa pierwotne, wąskie grupy religijne i ideologiczne enklawy” (Mead 2000, s. 23), w których przekaz poziomy informacji w obrębie grup kulturowych, heterogenicznych jest minimalny: „spotykamy [...] pod koniec XX wieku jednostki, które żyją jak pięćdziesiąt tysięcy lat temu. Możemy dziś znaleźć pierwotnych rybaków, myśliwych i ludzi, którzy dla uzyskania mizernych zbiorów używają jedynie zakrzywionych kijów. Możemy znaleźć ludzi żyjących w miastach rządzonych do dziś w stylu teokratycznym i jednowładczym; chłopów, których los nie zmienił się od wieków - żyją zamknięci w swoich wsiach i odgrodzeni od miejskiej kultury [...]. Żyjemy w czasach, gdy tubylcy z Nowej Gwinei, patrząc na kilka bulw ziemniaczanych, potrafią jedynie powiedzieć „dużo”, bo nie umieją liczyć, a jednocześnie zespoły naukowców na Przylądku Kennedy’ego obliczają z dokładnością do sekundy, kiedy statek Apollo musi zmienić kurs, by wejść w orbitę wokół Księżyca" (Mead 2000, s. 7-8).

Postrzeganie edukacji przez pryzmat promocji zmiany implikuje zatem postulat „trwałego wbudowania w mechanizm praktyki pedagogicznej zdolności reagowania na tę zmianę, a nawet uczestniczenia w jej stymulowaniu" (Witkowski

ograniczenia prawne i obyczajowe, które powstały z potrzeby współżycia; przez podział pracy, przez małżeństwo, przez własność stwarza warunki uporządkowaniu zaspokojonych popędów. W ten sposób uwalnia od ich straszliwej przemocy; życie zyskuje przestrzeń dla wyższych przeżyć i dążeń duchowych, te zaś są w stanie zdobyć przewagę" (Dilthey 1987, s. 202-203). 
1988, s. 135). Spór o zmianę edukacyjną jest bowiem zawsze też „sporem o zmianę społeczną" (Witkowski 1988, s. 136) - każde działanie edukacyjne stanowi formę realizacji jednego z możliwych modeli wychowania pożądanego lub niechcianego ze względu na polityczne uwikłania systemu edukacyjnego.

To formacja polityczno-społeczna w zasadniczym stopniu decyduje o tym, który z tych dwóch podstawowych paradygmatów wychowania determinuje charakter oddziaływań systemowych w instytucjach: czy wychowanie rozumiane jest jako „intencjonalne oddziaływanie na osobowość”, urabianie wychowanka i przystosowywanie go do „pełnienie określonych ról społecznych” - jak to się dzieje na gruncie teorii wywodzących się z założeń behawioryzmu; czy też pojmowane jest ono jako „wyzwalanie aktywności człowieka” (Folkierska 199o, s. 100), prowadzenie go „ku wolności”", zrodzonej z jego autonomicznej tożsamości podmiotowej (por. Carlgren, Klingborg 2010, s. 310-311), jak to ma miejsce w różnych odmianach pedagogiki emancypacyjnej/alternatywnej.

Ta opozycja ma fundamentalne znaczenie nie tylko dla wszelkiej refleksji nad wychowaniem, lecz także dla sensu życia człowieka w ogóle. Traktowanie wychowania jako planowej i systematycznej realizacji „względnie trwałych zmian osobowości” jest „wyrazem apoteozy czynu”, przedkładaniem racji nad poszukiwanie prawdy. $Z$ reguły mamy wtedy do czynienia $z$ „doktrynami-teoriami, zakładającymi tzw. naukowy światopogląd” (Szołtysek 1986, s. 108), przy czym przydawka „naukowy” jest w rzeczywistości semantycznie pusta i ma służyć legitymizacji naukowej prawomocności konstruowanych na ich podstawie technologii wychowania ${ }^{9}$. Nauka nie jest bowiem narzędziem uzasadniania ważności roszczeń

7 Wolność należy do klasy pojęć najpowszechniej stosowanych, ale i najbardziej rozmytych w sensie ich zawartości semantycznej w języku w ogóle, a w filozofii, socjologii czy pedagogice w szczególności. W przestrzeni społecznej problem z jego denotacją polega przede wszystkim na precyzyjnym „określeniu klasy czynów leżących poza stosowaniem prawa w sensie właściwym, czyli takich, których ktoś może dokonywać”. Sens tej aporii uchwycił Georg Christoph Lichtenberg, formułując w swoich aforystycznych „Brulionach” istotę wolności à rebours: „Tym, co najwyraźniej charakteryzuje prawdziwą wolność i prawdziwą możność korzystania z niej, jest jej nadużycie" (Lichtenberg 2005, s. 275).

8 Krzysztof Konarzewski twierdził np., że „wychowanie jest działalnością, w której jeden człowiek stara się zmienić innego człowieka" (Konarzewski 1982, s. 5-7), a Wincenty Okoń definiował wychowanie jako „świadomie organizowaną działalność ludzką, której celem jest wywołanie zamierzonych zmian w osobowości człowieka" (Okoń 1981, s. 348).

9 Wiele prac z dorobku okresu PRL obarczone było jednak ideologiczną wadą ortodoksyjnej neomodernistycznej koncepcji społeczeństwa i człowieka, mieszcząc się w „szerzej pojętym paradygmacie pedagogiki instrumentalnej” (Hejnicka-Bezwińska 1990, s. 158), pedagogiki „dworskiej” (Kwieciński 1982), „projektującej całościowe systemy oświecenia” (Hejnicka-Bezwińska 1995, s. 33), bez rzeczywistych rozwinięć konsekwencji analityczno-systemowych i pozostając często na poziomie modeli funkcjonalnych, postulujących totalność oddziaływań wychowawczej indoktrynacji społeczeństwa socjalistycznego. Przykładem może być tu pozbawiona wymiaru refleksji aksjologiczno-teleologicznej koncepcja teorii wychowania Heliodora Muszyńskiego, mająca charakter pragmatycznej, mechanistycznej technologii systemowej z elementami uproszczonej 
takich hipotez, teorii czy doktryn do prawdziwości, doktryn będących jedynie pragmatycznym zbiorem psychospołecznych przekonań o świecie" (Szołtysek 1986), lecz zajmuje się ujawnianiem prawdy o świecie odkrywanym i opisywanym przez podmiot poznający. Między nauką a światopoglądem, który jest zawsze „kreowany przez społeczną naturę człowieka na gruncie określonych racji i ujmowany w uporządkowany ciąg wartości” istnieje „teoriopoznawcza rozłączność" (Szołtysek 1986, s. 109). Każda zasadnie skonstruowana teoria naukowa musi odwoływać się do poznania naukowego, aby na jego podstawie sformułować środki i metody postępowania „doprowadzającego do ujawnienia dobra-celu społecznego lub państwowego, lub teistycznego" (Szołtysek 1986, s. 112). Już Arystoteles pisał, że sfera poznawcza (logos) powinna poprzedzać sferę działania (etos): najpierw należy poznać, aby wiedzieć, jak postępować ${ }^{10}$.

Etos jest naturalnym następstwem logosu. Wszelkie teorie-doktryny pedagogiczne, które próbują odwrócić tę sekwencję, „programowo powodują nieobliczalne następstwa w procesie wychowania" (Szołtysek 1986). Stanowią one w istocie wierne odzwierciedlenie przewrotnej formuły, jaką w Fauście J. W. Goethego wypowiada Mefistofeles, trawestując biblijną (ale w istocie o rodowodzie heraklitejskim) formułę otwierającą Ewangelię według św. Jana: „Na początku było słowo” - „Na początku był czyn" (Goethe 1967) ${ }^{11}$.

cybernetyki. Muszyński twierdził, że „wychowanie to celowe i zamierzone oddziaływanie na psychikę człowieka, zwłaszcza na osobników dorastających społecznie" (Muszyński 1976, s. 25). Szerzej na temat krytyki „technologii wychowania” (zob. Głażewski 1996, s. 36-37).

10 „Na to, by obywatele stawali się dobrymi i cnotliwymi, wpływają trzy czynniki; są nimi: natura, przyzwyczajenie, rozum. Przede wszystkim bowiem trzeba się urodzić człowiekiem, a nie jakąś inną istotą żyjącą, z odpowiednimi właściwościami ciała i duszy. Co do pewnych cech i urodzenie niczego nie przesądza, bo przyzwyczajenie powoduje ich zmianę. Są mianowicie pewne właściwości przyrodzone, które przez przyzwyczajenie ulegają zmianie tak w jedną, jak i w drugą stronę: na gorsze i na lepsze. Inne istoty przeważnie żyją wedle swej natury, niektóre w drobnych szczegółach urabia i przyzwyczajenie, ale tylko człowiek kształtuje się pod wpływem rozumu, bo on tylko rozum posiada. Toteż wszystkie te trzy czynniki muszą być u niego zharmonizowane" (Arystoteles 2001, s. 203-204). Arystoteles wskazuje zatem na trzy czynniki rozwojowe: physis (organizm biologiczny), ethos (obyczaj, przyzwyczajenie) oraz logos (rozum, umysł) „człowieka, który może działać wbrew ludzkim przyzwyczajeniom i ich naturze, jeśli dojdzie do przekonania, że lepiej jest inaczej" (Kunowski 1993, s. 186).

11 „Oto pierwotny tekst otworzę i pełen godnego zapału Najświętszą treść oryginału Na drogi język ojczysty przełożę [otwiera tom i zaczyna]. Pisano jest: «W początku było słowo». Cóż czynić? Trudność już widzę gotową. Przecie nikt słowa cenić tak nie może; A więc inaczej to przełożę, jeśli się zdołam w strefę duch wznieść. Pisano jest: «W początku była treść». [...] Czyż wszystko treść zdziałała i stworzyła? Powinno być: «W początku była siła». Lecz również teraz pióro me się wzdraga; Aż nagle czuję, że duch mnie wspomaga. Mam rozwiązanie bez skaz i bez win. I piszę już: «Był na początku czyn»" (Goethe 1967, s. 74-75). W polskiej pedagogice to Florian Znaniecki pisał: „Istnieć - to wszędzie znaczy działać” (Znaniecki 1987, cyt. za: Szacki 1986, s. 200). Wrastanie jednostki w zastane społeczeństwo miała dla niego charakter prymarny. Dopiero po pełnej adaptacji ludzie „powołani na przewodników innych” (Znaniecki 1964, s. 129) 
Wychowanie oparte na takiej Mefistofelesowskiej formule sprowadza się do logiki pozorów, do „nadawania niewiedzy pozorów wiedzy naukowej” - tzn. do formułowania tzw. światopoglądu naukowego, ideologii - nie wiedzy. Teorie wychowania są tylko doktrynami wychowania, ich podstawą bowiem jest rzeczywistość nie taka, jaka jest obiektywnie, lecz taka, jaka być powinna w mniemaniu autorów tych teorii. Stąd uporczywe głoszenie konieczności urabiania wychowanka, aby to on dopasował się do postulowanego ładu społecznego ${ }^{12}$.

Zasadniczym punktem sporu między teoriami postbehawioralnymi a emancypacyjno-humanistycznymi jest więc status zmiany, sposób i cel jej wychowawczego kreowania w sekwencji logosu i etosu: „Spornym pozostaje tylko pytanie, czy owym podmiotem, będącym w istocie przedmiotem, zawiadywać, manipulować, sterować itp., czy nie przeszkadzać mu w rozwijaniu tkwiących w nim możliwości autentycznego i spontanicznego przeżycia, wzrostu, rozwoju i samorealizacji”" (Folkierska 1990, s. 101) ${ }^{13}$.

Ten pierwiastek wolności wychowywania i stawania się człowieka stanowił na przełomie XIX i XX wieku o mocy krytyki przedstawicieli Nowego Wychowania, zwróconej przeciw formalizmowi pedagogiki herbartowskiej ${ }^{14}{ }^{1}$ wciąż wyznacza pole konfrontacji nurtów pozytywistyczno-oświeceniowych i „romantycznych”

mogli dokonywać zmian. „Człowiek ze swej natury „musi poddać się porządkowi, jaki już przed nami wytworzony został i jaki dookoła siebie zastajemy; przestajemy istnieć jako duch, jako świadomość, jako ciało, o ile przekazywanej nam rzeczywistości zaprzeczamy” (Znaniecki 1987, S. 199).

12 Por. np. koncepcję wychowania Stanisława Kowalskiego jako „dorastania do zadań wynikających z perspektywy rozwoju danego społeczeństwa” (Kowalski 1979, s. 15). Podstawową funkcją wychowania jest „przygotowanie dorastających pokoleń do czynnego i twórczego uczestnictwa w dynamice postępu społeczno-kulturalnego (Kowalski 1979, s. 16). Wychowanie „naturalne” w rodzinie powinno wg Kowalskiego podlegać przemożnemu wpływowi wychowania instytucjonalnego, celowego, organizowanego przez i dla społeczeństwa (por. Głażewski 1996, s. 35).

13 Zbigniew Kwieciński pyta: „Czy i co szkoła może zrobić dla przebudowy zasady organizującej system? Weźmy pod uwagę to, iż nie śni mi się zmiana szybka, ani też zrealizowana gwałtownymi metodami. Kryzys daje nam szczególnie wydłużoną perspektywę realizacji większych nadziei. A zatem trzeba przygotować nowe pokolenia dla celowej, stopniowej zmiany, ucząc i ćwicząc je w kooperacji, w technikach prowadzenia dyskursu otwartego, wzajemnej szczerości, uporczywym treningu w myśleniu krytycznym i alternatywnym, w wybieraniu trafnych utopii i umiejętności odkładania gratyfikacji z racji jej zrealizowania” (Kwieciński 2011, s. 163).

14 „Spokojnie i cierpliwie śledzić, jak natura sama sobie radzi, a baczyć tylko na to, by warunki otaczające pracę natury wspierały - oto jest wychowanie” (Key 2005, s. 65). I potem dodaje: „Wychowywać dziecko - znaczy piastować duszę jego na ręku, stawiać kroki jego na wąskiej ścieżynie. Znaczy to nie narazić się nigdy na niebezpieczeństwo ujrzenia we wzroku dziecka chłodu, który nam bez słów mówi, iż my mu nie wystarczamy i uważa nas za niekonsekwentnych; znaczy to uznać z pokorą, iż możliwość szkodzenia dziecku trafia się często, a dopomożenia mu rzadko. [...] Najlżejsza nieufność, najdrobniejsza niedelikatność, maleńka niesprawiedliwość, ulotne szyderstwo pozostawiają palące piętna w czułej duszy dziecka, podczas gdy znowu niespodziewana łagodność, sprawiedliwy gniew również głęboko wrażają się w pamięć i w zmysły, które nazywamy miękkimi jak wosk, a traktujemy jak wołową skórę!” (Key 2005, s. 68-69). 
pedagogiki. Rozwój człowieka wyznaczany przez sekwencję logos-ethos - „stawanie się, rozumiane jako wysiłek istnienia, wysiłek bycia” (Folkierska 1990, s. 101) - zawierała już w okresie międzywojennym koncepcja Sergiusza Hessen, który pisał wprost o „dorabianiu się osobowości” (Hessen 1973) czy późniejsze prace z zakresu antropologii filozoficznej Bogdana Suchodolskiego (Suchodolski 1985) ${ }^{15}$. Wychowanie w takich humanistycznych czy „romantycznych” koncepcjach człowieka polega na stwarzaniu wychowankowi warunków do przyswajania sobie takiej wiedzy i doświadczenia, aby w rozwoju swoim osiągnął on tożsamość podmiotową „zdobywaną w wysiłku bycia bytu przytomnego (Dasein) w świecie. Wysiłek ów jest tworzeniem samowiedzy osiąganej w powracaniu do siebie od tego, co inne, to znaczy w teoretyczno-praktycznym przyswajaniu sobie tego, co «obce», niezrozumiałe, nieprzejrzyste. To przyswajanie jest dialektyką posłuchu i nieposłuszeństwa, dialektyką, która jest samą «istotą» doświadczenia wychowującego. Wysiłek bycia jest zmierzaniem ku prawdzie, jest doświadczaniem prawdy wciąż na nowo uobecnionej w negatywności samego doświadczenia” (Folkierska 1990, s. 110) ${ }^{16}$.

Ów wysiłek ku zmianie nie powinien być degradowany przez pragmatyczno-ideologiczne zabiegi pedagogiczne, mające na celu urabianie jednostki przez indoktrynację w postaci sądów i opinii o rzeczywistości społecznej przezeń postulowanej ${ }^{17}$, ale promowany w kontekście empirycznego, prakseologicznego i hermeneutycznego wymiaru pedagogiki - jako nauki i jako sztuki prowadzenia człowieka

15 W szczególności rozdział Na początku był czyn: Suchodolski dowodzi w nim, że dla człowieka „charakterystyczny jest «nadmiar sił popędowych». [...] Człowiek dysponuje energia ponad poziom tego, co życiowo konieczne, [...] jest istotą nigdy nie zaspokojoną, wciąż pożądającą i wciąż poszukującą. Gehlen sądzi, iż szczególnie ważną cechą istoty ludzkiej jest właśnie to, że popędy jej nie wyspecjalizowane w ograniczonych, sztywno wyznaczonych kierunkach, muszą być «gotowe» na różne okoliczności, a więc «chronicznie» żywe, a nie tylko okresowo aktywne, a zarazem muszą być w określonych sytuacjach i momentach powstrzymywane. Ten konstrukcyjny nadmiar popędowy, utrzymywany w rozwoju człowieka długim, igrającym dzieciństwem, jest więc swoistym odpowiednikiem tej podstawowej właściwości, która [...] czyni człowieka stworzeniem wielorako otwartym na świat, stawiając go w sytuacjach trudnych, zmiennych, wcale nie sprzężonych z jego sposobami reakcji” (Suchodolski 1985, s. 203-204).

16 Tożsamość może być tu definiowana jako „zespół wyobrażeń, uczuć, sądów, wspomnień i projekcji podmiotu, który odnosi on do siebie. W pojęciu tym mieszczą się takie składniki, jak: samoświadomość jednostki, świadomość kontynuacji i pozostawania sobą w zmieniających się warunkach życia, świadomość uczestnictwa podmiotu w grupach społecznych, koncepcja siebie, zdolność do porównań interpersonalnych i grupowych” (Kamiński 1996, s. 77).

17 Zbigniew Kwieciński wskazuje tu na nowy charakter klasowego oblicza społeczeństwa: „Cztery hipotezy wyłaniania się nowej stratyfikacji i nowych elit: kapitału politycznego, kapitału ludzkiego; mobilności sektorowej, przedsiębiorczości. [...] Cztery propozycje (co w miejsce klas społecznych): 1) kulturalizm (style życia i konsumpcji, wybory estetyczne, korzystanie z informacji, osiągnięcia intelektualne, uznawane wartości); 2) fragmentacja (podobna do klasowej, ale dynamiczna i globalna); 3) atomizacja (dobory według poziomu wykształcenia, wzorów małżeństwa i dochodów, samoidentyfikacji); 4) zmiana znaczenia - resignifikacja (resignification) oparta na wyborach i zainteresowaniach subiektywnych" (Kwieciński 2012, s. 382). 
do życia wartościowego, a więc sensownego (por. Gnitecki 1989a; Gnitecki 1989b; Gnitecki 1989c).

Promocja rekonstrukcyjnej funkcji wychowania (zmiany rozwojowej) ma zawsze jednak charakter probabilistyczny, ponieważ jest zapośredniczona każdorazowo w niepowtarzalnym „porządku życia” człowieka: jest on zarazem źródłem i celem tworzenia siebie - transgresji, przekraczania siebie - aby w tej ciągłej zmianie wciąż pozostawać tożsamym Ja; bo przecież „człowiek nie potrzebuje być kimś innym, aby być sobą, lecz nie wystarcza mu również to, jaki jest i taki już będzie. [...] Człowiek jest kimś przez to, że staje się sobą" (Łukaszewicz 1990, s. 286) - tzn. im bardziej się zamienia, tym bardziej pozostaje ten sam (ale nie taki sam) - wciąż stając się kimś - sobą samym.

Szczególnym miejscem tego sporu o wychowanie, jako inkulturację, jest szkoła jako społeczna instytucja edukacyjna. W rzeczywistości stanowi ona specyficzne „pole napięć”, jest wypadkową mnogości rozmaitych sił, wpływów i interesów, zatem jej struktura i funkcja są swoistym konglomeratem „różnorodności praktyk pedagogicznych" (Berg 1983, s. 108) i czynników pozapedagogicznych o pluralistycznym autoramencie. W niej pokłada się a priori nadzieje na realizację wielorakich funkcji kulturowych: „To przecież szkoła - obok rodziny - jest główną agendą socjalizacji, przez co zapewnia ciągłość wartości, norm kulturowych, a więc ciągłość społeczeństwa. To szkoła w momentach przełomowych przygotowuje (a przynajmniej powinna to robić) do koniecznych zmian społecznych, do innowacji" (Sawisz 1989, s. 5).

Jednak w świetle badań nad polską szkołą te jej założone funkcje jawią się jako bardziej niż wątpliwe. Zbigniew Kwieciński zaliczył je do „złudzeń endogennych co do istoty oświaty" (Kwieciński 1987, s. 88). Pokazał, że szkoła ma minimalny wpływ na wychowanie, a między przekazywanymi przez nią treściami a rzeczywistością społeczno-kulturową występuje tak wielki rozziew, że „dopiero po opuszczeniu szkoły następuje reintegracja tożsamości, bez uwzględnienia wiedzy i doświadczeń wyniesionych ze szkoły" (Kwieciński 1987, s. 91). Szkoła jawi się w tych konkluzjach zdecydowanie jako „inhibitor zmiany” (Kwieciński 1988, s. 9), a nie jej promotor.

Długoletnie uczęszczanie do szkoły oparte na powszechnym obowiązku szkolnym $^{18}$ ma w rzeczywistości „mitotwórczy charakter” (Kwieciński 1990, s. 238). Rodzicom i uczniom każe się mianowicie wierzyć, że szkoła przekazuje niezbędną im wiedzę i wprowadza w dorobek kultury narodowej i edukacyjnej, że: „wspiera rozwój indywidualności, tożsamej osobowości, że jest pożytecznie zorganizowanym czasem dzieciństwa i wczesnej młodości, że właściwie wprowadza w życie społeczne i obywatelskie, uczy demokracji, ustawicznego wyboru, krytycyzmu,

18 Nie wszędzie w świecie ten obowiązek jednak istnieje: nie ma go w takich krajach Trzeciego Świata, jak Kamerun, Wybrzeże Kości Słoniowej czy Sierra Leone, ale też nie istnieje w niektórych stanach Stanów Zjednoczonych Ameryki Północnej - Missisipi, Karolinie Północnej i Karolinie Południowej. 
samookreślania się. Wiara ta nie tylko nie ma pokrycia w faktycznych funkcjach szkoły, ale jest tym silniejsza, im mniejsze sukcesy w swym rozwoju odniosła wobec dzieci i młodzieży" (Kwieciński 1990).

Szkoła natomiast, deklarując funkcję medium transmisji kulturowej, tak naprawdę pełni „funkcję diafragmatyczną, przesłonową, przerywającą pamięć pokoleniową” przez „historyzm swych treści i wieloletnie oderwanie dzieci i młodzieży od problemów bieżącego życia społecznego" (Kwieciński 1990, s. 240).

Szansy na autentyczne i wartościowe sprawstwo edukacyjne instytucji szkoły Kwieciński upatruje w wychowaniu rozumianym jako „spotkanie rówieśników i młodzieży z dorosłymi”, postulując zarazem rezygnację z „fasadowych wysiłków wychowawczych" na rzecz realizacji funkcji szkoły ,jako moratorium w rozwoju tożsamości, gdzie młodzież «przymierza się» $\mathrm{i}$ «gra» różne próbne role i różne odmiany siebie" (Kwieciński 1987, s. 89).

\section{Symulakrum jako heurystyczne narzędzie analizy edukacji}

Powyższy, tak bardzo złudny obraz instytucji szkoły w świadomości społecznej jako miejsca socjocentrycznej transmisji kulturowej w tradycyjnym rozumieniu pedagogiki Herberta tak bardzo odbiega od rzeczywistości, że można się nawet pokusić o objaśnienie go za pomocą aplikacji kategorii symulakrum. Czyż bowiem szkoła jako pojęcie, znak, emblemat w swej recepcji społecznej nie skrywa faktu, że edukacja jako taka nie funkcjonuje w sensie przynależności do porządku ontologicznego, a istnieje jedynie jako symulacja rzeczywistości - pozór, ułuda symulakrum właśnie?

Symulakrum bądź symulakr (łac. simulacrum - 'podobieństwo, pozorność') jest obrazem, pozorem (une apparence) czy szyldem stanowiącym czystą symulację, udającym rzeczywistość, nie pozostając wobec niej w żadnej faktycznej relacji, bądź nawet tworzącym własną rzeczywistość.

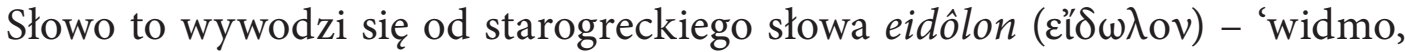
obraz, obraz boga', które w języku łacińskim przybrało formę idolum, co jest tłumaczone jako 'udawanie, pozór, złuda' i przeciwstawiane słowu icona (gr. eikôn,

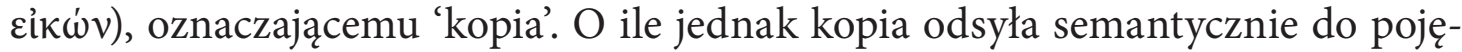
cia imitacji rzeczywistości, bez jej dysymulacji, tzn. utajania czy skrywania, to eidôlon odrywa się od niej w formie gr. eidos albo idea (i $\delta \dot{c} \alpha$ ), tłumaczonych jako 'forma, kształt, powierzchowność, zarys'. Słowo eidolon pojawia się w dziełach Platona (Sofista) (Platon 1956), ale również w presokratejskiej filozofii przyrody (u Demokryta - cząsteczki, „podobizny” wysyłane przez przedmioty i wywołujące wrażenia zmysłowe) i u epikurejczyków.

Symulakrem (idolem) może być także przedmiot wyobrażający postać nadprzyrodzoną czy fantastyczną, sporządzany dla celów magicznych, rytuałów religijnych, potrzeb naukowych i dydaktycznych (artefakt) lub ludycznych (lalka). Niekiedy 
idole są wyposażone w cechy, legitymujące ich prawomocność, np. mechanizmy poruszające je albo realistyczne atrybuty animistyczne.

Symulakrum jako termin filozoficzny został na nowo włączony do współczesnego dyskursu naukowego przez Jeana Baudrillarda ${ }^{19} \mathrm{w}$ postaci oryginalnej koncepcji ewolucji znaków, tzw. teorii symulacji, w jego programowej pracy Symulakry i symulacja (Baudrillard 2005): wraz z rozwojem systemów semiotycznych (znakowych) granica między światem rzeczywistym a formami jego przedstawień z wolna, lecz nieuchronnie ulega zniesieniu, zanika, co skutkuje coraz większym uniezależnieniem się znaku. Stadia tego procesu emancypacyjnego Baudrillard określił mianem symulakrów. W jego toku następuje zatrata funkcji referencyjnej znaku - „symulakrum nie skrywa już rzeczywistości, ono skrywa, że rzeczywistość nie istnieje. To symulakrum jest prawdziwe"20.

Epigeneza symulakru wraz z procesem symulacji rzeczywistości zapośredniczona jest $\mathrm{w}$ niejednoznacznym ontologicznie statusie znaków podlegających procesowi uniezależniania się - z jednej strony znaki nie istnieją fizycznie w czasie ani w przestrzeni, z drugiej nie funkcjonują jako abstrakcyjne elementy jakiegoś nadrzędnego systemu semantycznego. Natomiast symuluja one swe rzeczywiste istnienie, analogicznie do chorego, który symuluje chorobę, tzn. wywołują autentyczne symptomy przynależne zjawiskom rzeczywistym, wchodzą z otaczającym światem w rzeczywistą interakcję ${ }^{21}$. To ich pozorne istnienie prowadzi do powstania symulakrów rzeczywistości podwojonej (Łotman 2008, s. 57-58), a w konsekwencji niemożliwości odgraniczenia zjawisk porządku ontologicznego od porządku znakowego. Ten stan symulowania symulacji Baudrillard określił mianem hiperrzeczywistości ${ }^{22}$.

19 Jean Baudrillard (ur. 1929 roku w Reims, zm. 2007 roku w Paryżu) - francuski socjolog i filozof kultury, inicjator nurtu postmodernistycznego w teorii kultury, jeden z najwnikliwszych krytyków globalizacji, społeczeństwa postindustrialnego i kulturowych skutków rozwoju technologii rzeczywistości wirtualnej. Po polsku ukazały się jego prace: Ameryka (1998), Rozmowy przed końcem (2001), Pakt jasności. O inteligencji zła (2005), Duch terroryzmu. Requiem dla Twin Towers (2005) i O uwodzeniu (2005), Społeczeństwo konsumpcyjne, jego mity i struktury (2006), W cieniu milczącej większości albo kres sfery społecznej (2006), Wymiana symboliczna i śmierć (2007).

20 Le simulacre n'est jamais ce qui cache la vérité - c'est la vérité qui cache qu'il n'y en a pas. Le simulacre est vrai (Baudrillard 1981, s. 9).

21 „Dysymulować - 'ukrywać lub taić - oznacza udawać, że nie posiada się tego, co się ma. Symulować oznacza udawać, że posiada się to, czego się nie ma. Pierwsze odsyła do obecności, drugie do nieobecności. Sprawa jest jednak bardziej skomplikowana, gdyż symulowanie nie oznacza udawania: «Ten, kto udaje jakąś chorobę, może zwyczajnie położyć się do łóżka i przekonać innych, że jest chory. Ten, kto symuluje chorobę, wywołuje w sobie niektóre z jej objawów» (Littré). Udawanie i ukrywanie pozostawiają zatem zasadę rzeczywistości nietkniętą: różnica jest zawsze wyraźna, pozostaje tylko w ukryciu" (Baudrillard 2005, s. 8).

22 „Co to znaczy, że nie ma już rzeczywistości? To mianowicie, że nie sposób już dotrzeć do niezapośredniczonego jej poziomu, do tego, co absolutnie rzeczywiste. Jeśli jednak coś naprawdę 
Sformułowanie przez Baudrillarda w latach 80. XX wieku pojęcia symulakru jako kategorii filozoficznej stało się ważną inspiracją dla rozwoju całego nurtu późnej refleksji postmodernistycznej w filozofii kultury i socjologii, przybierając postać praktycznego narzędzia metodologicznego analizy zjawisk kultury masowej. Jednakże mnogość generowanych przez to pojęcie kontekstów i punktów odniesienia oraz dość hermetyczny język dyskursu postmodernistycznego sprawiają, że efektywne zdefiniowanie zakresu semantycznego, w którym można by je aplikować, jest dość trudne. Sam Baudrillard kategorię symulakru stosował do analizy takich zjawisk, jak istnienie wizerunku Boga i jego recepcja kulturowa ${ }^{23}$, powstanie i funkcje instytucji Disneylandu ${ }^{24}$, społeczna rola fotografii, a także rozmaite aspekty popkultury: mass mediów, filmu, twórczości science-fiction, reklamy, instytucji hipermarketu.

Baudrillard odróżnia trzy porządki symulakrów:

a) symulakry naturalne, naturalistyczne, oparte na obrazie, naśladownictwie i podrabianiu, harmonijne, optymistyczne oraz zmierzające do przywrócenia, odtworzenia bądź ustanowienia w sposób idealny natury na wzór Boga;

b) symulakry produktywne, produktywistyczne, oparte na energii, sile, zmaterializowane za pomocą maszyny w całym systemie produkcji - ich prometejskim celem jest globalizacja i bezustanna ekspansja, uwolnienie nieskończonej energii (pragnienie energii stanowi część utopii wiążących się z tym porządkiem symulakrów);

zniknęło, to różnica między tym, co rzeczywiste i tym, co wyobrażone. Zamiast niej, likwidując ów tradycyjny podział, będący fundamentem filozofii przedstawienia, rozrasta się hiperrzeczywistość: rzeczywistość bardziej rzeczywista od samej rzeczywistości, jak w przypadku symulowanych lotów kosmicznych czy komputerowych symulacji naturalnego środowiska. Czy żyjemy wobec tego w świecie iluzji, jak domniemywali wszyscy postkantyści (a właściwie postschopenhaueryści), dla których świat równał się wyłącznie światu wyobrażonemu, przedstawionemu? Oczywiście nie, albowiem iluzja istnieje tylko o tyle, o ile istnieje świat realny. Z chwilą, gdy ten staje się niemożliwy (do uchwycenia), niemożliwe staje się też złudzenie. [...] Rzeczywistość nie niknie na rzecz wyobraźni, lecz na rzecz tego, co bardziej rzeczywiste od rzeczywistości: hiperrzeczywistości” (Markowski 2001, s. 178-179).

23 „Wściekłość, z jaką pragnęli niszczyć obrazy [ikonoklaści - M. G.], wypływała właśnie z tego, że przeczuwali ową wszechwładzę symulakrów, posiadaną przez nie zdolność wymazywania Boga z ludzkiej świadomości, oraz ową zgubną i unicestwiająca prawdę, której można się domyślać: w rzeczywistości Boga nigdy nie było, istnieją jedynie symulakry, sam Bóg był zaś jedynie swym własnym symulakrem" (Baudrillard 2005, s. 10).

24 „Disneyland istnieje po to, by zataić fakt, że «rzeczywisty» kraj, cała «rzeczywista» Ameryka jest Disneylandem (trochę podobnie jak więzienia, które istnieją po toby ukryć to, że cale społeczeństwo w swej banalnej wszechobecności ma charakter karceralny). Disneyland przedstawia się jako przestrzeń wyobrażoną, by przekonać nas, że reszta jest rzeczywista, podczas gdy w istocie całe Los Angeles i otaczająca je Ameryka rzeczywistymi już nie są, lecz należą do porządku hiperrzeczywistości i symulacji”" (Baudrillard 2005, s. 19). 
c) symulakry symulacji, oparte na informacji, modelu, cybernetycznej grze całkowita operacjonalizacja, hiperrzeczywistość, celem ich jest uzyskanie całkowitej kontroli (Baudrillard 2005, s. 149).

Pierwszemu z tych porządków odpowiadają wyobrażenia utopii, drugiemu literackie konstrukcje beletrystyczne science-fiction, trzeci natomiast „zaczyna się właśnie wyłaniać [...], gdy dystans, włączając w to dystans dzielący rzeczywistość od wyobrażenia, zaczyna zanikać, ulega wchłonięciu, a na jego miejscu pojawia się model. [...] Modele nie stanowią już transcendencji ani projekcji, nie są wyobrażeniem w stosunku do rzeczywistości, same stanowią antycypację rzeczywistości, nie pozostawiają zatem miejsca na jakikolwiek rodzaj wyobrażeniowej transcendencji. Otwarte zostaje pole dla symulacji w sensie cybernetycznym, to znaczy dla wielokierunkowej manipulacji owymi modelami (scenariusze, inscenizacje symulowanych sytuacji itp.), jednak wówczas «nic nie odróżnia już owej operacji sterowania od operacji samej rzeczywistości: nie istnieje już fikcja»” (Baudrillard 2005, s. 149-150).

W paradoksalny sposób rzeczywistość stała się zatem prawdziwą utopią - „taką utopią jednak, która nie należy już do porządku możliwości, o której możemy jedynie marzyć jako o utraconym obiekcie" (Baudrillard 2005, s. 150) ${ }^{25}$.

Wydaje się, że taką utopią, symulakrem należącym do porządku trzeciego, stała się współcześnie edukacja, jako znak generujący symulację rzeczywistości, bardziej prawdziwej niż sama rzeczywistość (np. dyplomy jako emblematy wiedzy są bardziej realne niż sama wiedza).

\section{Edukacja jako symulakrum hipermarkietu}

W grudniu 2013 roku amerykański portal internetowy The Atlantic opublikował raport na temat kondycji szkolnictwa wyższego w USA (Pratt 2013). Nadał mu znamienny tytuł: Tworzymy Walmarty szkolnictwa wyższego. Walmart (Wal-Mart Stores, Inc.) to amerykańska sieć hipermarketów założona w 1962 roku przez Sama Waltona, największy na świecie sprzedawca detaliczny $(2010)^{\mathbf{2 6}}$, znana z najniższych cen (zasadą jest zysk w wysokości jednego centa na każdym oferowanym

25 Szerzej na temat utopii i jej derywatów - atopii, heterotopii i dystopii: por. Głażewski 2010.

26 Według nieoficjalnej klasyfikacji Wal-Mart uplasowałby się wśród gospodarek narodowych na 33. miejscu, między Ukrainą i Kolumbią. Sloganami sieci są: „Wal-Mart. Always Low Prices. Always” ('Zawsze niskie ceny. Zawsze’) oraz „Save Money. Live Better” ('Oszczędzaj pieniądze. Żyj lepiej’). Firma jest największym prywatnym pracodawcą w USA, Meksyku i Kanadzie w USA zatrudnia 1,8 mln osób, jest jednak krytykowana za wyzysk pracowników - zaniżanie płac, zakaz zakładania związków zawodowych i ograniczenie ubezpieczeń zdrowotnych. Charakterystyczną cechą sieci Wal-Mart są bardzo niskie ceny produktów, co powoduje, że kupują w niej najuboższe grupy ludności. Za: Wikipedia, dostępny na: http://pl.wikipedia.org/ wiki/Walmart (otwarto: 12.12.2013). 
produkcie), niskiej jakości towarów, identycznych procedur organizacji handlu i ogromnego wolumenu sprzedaży.

Autor raportu przyrównuje amerykańskie szkoły wyższe - college i uniwersytety - do tych gigantycznych hipermarketów nastawionych wyłącznie na obrót i zysk. Podaje alarmujące przykłady tego mechanistyczno-redukcjonistycznego syndromu merkantylizacji edukacji: uniwersytety w Dakocie Południowej, Nebrasce i innych stanach USA radykalnie redukują liczbę przedmiotów (kursów), które studenci muszą zaliczyć. Na Florydzie kursy internetowe mają stopniowo zastępować tradycyjne formy kształcenia uniwersyteckiego. W Kalifornii wprowadza się rozwiązania prawne pozwalające tego typu edukację internetową subsydiować również na uniwersytetach państwowych. Uniwersytet w Karolinie Północnej pozbywa się z programów studiów historii, nauk politycznych i wielu innych „nisko produktywnych” kursów edukacyjnych, a kanclerze uniwersytetów na Florydzie, w Karolinie Północnej i Wisconsin poddają pod wątpliwość, czy aby na pewno podatnicy powinni płacić za nauczanie na uniwersytetach stanowych przedmiotów humanistycznych.

Powstaje presja, aby w jak najkrótszym czasie i jak najniższym kosztem „wyedukować" jak największą liczbę studentów, wiążąc przy tym kompetencje absolwentów bezpośrednio z potrzebami rynku pracy. Oznacza to redukowanie liczby wymaganych zaliczeń, podnoszenie znaczenia praktyki kosztem teorii, usuwanie z programu niektórych kursów i przenoszenia ich do internetowej sfery online.

Krytycy biją na alarm: takie praktyki powodują deprecjację edukacji uniwersyteckiej, obniżanie jej poziomu. Pod egidą Campain for the Future of Higher Education (Ruchu na Rzecz Przyszłości Edukacji Uniwersyteckiej) przestrzegają przed zbyt pospiesznym parciem w kierunku zwiększenia efektywności kształcenia kosztem jego jakości, twierdząc, że nie ma naukowych dowodów na rzeczywistą wartość edukacyjną masowych kursów internetowych, nawet jeśli uczestniczy w nich coraz większa liczba studentów. (Badania przeprowadzone przez Uniwersytet w Pensylwanii pokazały, że tylko cztery proc. zapisanych na te kursy studentów kończy je zaliczeniem): „Tworzymy Walmarty szkolnictwa wyższego - wygodne, tanie i niskiej jakości” (Pratt 2013). Renesans przeżywa pojęcie „McDonaldyzacji” edukacji, wprowadzone do dyskursu społecznego w 1983 roku przez socjologa Georga Ritzera (Ritzer 2003) dla opisania trendu dehumanizacji na rzecz afirmacji wydajności i kontroli. Rezultaty presji na „wydajność uniwersytecką” wynikają z frustracji polityków w obliczu statystyk: tylko 56,1 proc. studentów kończy studia w ciągu sześciu lat. Jednak „idea, że system funkcjonuje prawidłowo, a my powinniśmy przepuszczać studentów jeszcze szybciej, jest błędna” (Pratt 2013).

Amerykanie szukają rozwiązań, wiedząc, że nie istnieje jeden radykalny sposób przemiany: tworzenie tzw. środowisk edukacyjnych (so-called learning communities), w których grupy studentów będą wspólne uczestniczyć w kursach przedmiotowych, może podnieść ich motywację i zmniejszyć liczbę rezygnujących ze studiów; podniesienie jakości interakcji z gronem dydaktycznym („Wszystko, 
co tworzy dystans w relacji nauczyciel-student, krzywdzi studenta"), uczenie się w formie zajęć eksperymentalnych poza murami uniwersyteckimi.

Taka diagnoza edukacji dobrze odpowiada symulakrowi hipermarketu autorstwa Baudrillarda: „Hipermarket przypomina wielką fabrykę montażową, do tego niemal stopnia, że podmioty (bądź przedmioty), ruchome i zdecentrowane, zamiast być spętane łańcuchem pracy przez jakiś racjonalny i bezustanny przymus, sprawiają wrażenie, jak gdyby przemieszczały się z jednego ogniwa łańcucha do drugiego po zupełnie przypadkowych trajektoriach. Kolejność, selekcja, zakup również rządzą się przypadkiem w odróżnieniu od działalności, jaką jest praca. Mimo wszystko mamy tu jednak do czynienia $z$ łańcuchem, zaprogramowaną dyscypliną, której zakazy uległy zamazaniu za sprawą równi pochyłej tolerancji, dostępność i hiperrealaności” (Baudrillard 2005, s. 96-97).

Tolerancja, dostępność i hiperrealność w coraz większym stopniu stanowią również atrybut naszej szkoły jako instytucji edukacyjnej: „odkąd funkcja ulega hiperspecjalizacji do tego stopnia, że może zostać zaprojektowana od początku do końca na miejscu, "pod klucz», traci właściwą sobie celowość i staje się czymś całkowicie innym: wielofunkcyjnym zbiorem "czarnych skrzynek» o wielu wejściach i wyjściach [...]. Te fabryki i uniwersytety nie są już żadnymi fabrykami ani uniwersytetami, a hipermarkety nie mają nic z rynku" (Baudrillard 2005, s. 98).

Wprowadzona w powyższym dyskursie krytycznym kategoria Baudrillardowskiego symulakrum może być jednym z wielu narzędzi hermeneutycznej analizy tak bardzo polimorficznego i polisemantycznego fenomenu społecznego, jakim jest edukacja ${ }^{27}$. Ten przyczynek nie rości sobie prawa do kompletności diagnozy ani niechybności interpretacyjnej. Nawet metafora hipermarketu nie jest oryginalna - pozostaje w socjologicznym nurcie analiz, dobrze reprezentowanych już choćby przez Georga Ritzera w jego tezie o makdonaldyzacji społeczeństwa czy na gruncie polskim - np. pogłębionych krytycznych analiz zjawisk edukacyjnych autorstwa Zbigniewa Kwiecińskiego, Lecha Witkowskiego, Bogdana Śliwerskiego czy Teresy Hejnickiej-Bezwińskiej.

Ten esej jest tylko rodzajem próby nazywania wewnętrznego niepokoju: czy aby polska edukacja, kurczowo wzorując się na pragmatycznej amerykańskiej standaryzacji i zasadzie efektywności, wprowadzając cybernetyczne założenia

27 Postmoderniści posługują się w tym kontekście terminem bricolage ( $\mathrm{z}$ fr. bricoler - 'wykonywać pracę bez znaczenia i przynoszącą mały zysk, majsterkować, dłubać przy czymś’) dla oddania sensu takiej konstrukcji narracji dyskursu: „Derrida i dekonstrukcjoniści zdają sobie dobrze sprawę z tego, że każde takie określenie [np. idealizm, kartezjanizm, metafizyka obecności M. G.] mimo immanentnych roszczeń znaczeniowych, implikujących możliwości uniwersalizacji, «wzmocniania» każdego z nich, ma swoje zastosowanie we właściwym mu kontekście pojęciowym i dyskursywnym - należałoby raczej nimi operować (bricolage), niż budować z nich teorie". Zob. Hartman J. (1997). Heurystyka filozoficzna. Wrocław: Wydawnictwo Leopoldinum Fundacji dla Uniwersytetu Wrocławskiego, s. 216. 
unitarnej edukacji wedle systemu bolońskiego, nie podąża tą drogą - ku symulakrowi hiperrzeczywistości supermarketu?

\section{Bibliografia}

Arendt H. (1961). Between Past and Future: Six exercises in political thought. New York: Viking Press (wyd. pol.: Arendt H. (1994). Między czasem minionym a przyszłym: osiem ćwiczeń z myśli politycznej, tłum. M. Godyń, W. Madej. Warszawa: Fundacja Aletheia).

Arendt H. (1991). Myślenie, tłum. H. Buczyńska-Garewicz. Warszawa: Spółdzielnia Wydawnicza „Czytelnik”.

Arystoteles (2001). Polityka, tłum. L. Piotrowicz. W: Arystoteles. Dzieła wszystkie. T. VI. Warszawa: PWN.

Baudrillard J. (2001). Ameryka, tłum. R. Lis. Warszawa: Wydawnictwo sic!

Baudrillard J. (2001). Przed końcem. Rozmowy z Philippe'em Petit, tłum. R. Lis. Warszawa: Wydawnictwo sic!

Baudrillard J. (2005). Symulakry i symulacja, tłum. S. Królak. Warszawa: Wydawnictwo sic!

Baudrillard J. (1981). Simulacres et simulation. Paris: Galilée.

Baudrillard J. (2005). Pakt jasności. O inteligencji zła, tłum. S. Królak. Warszawa: Wydawnictwo sic!

Baudrillard J. (2005). Duch terroryzmu. Requiem dla Twin Towers, tłum. S. Królak. Warszawa: Wydawnictwo sic!

Baudrillard J. (2005). O uwodzeniu, tłum. J. Margański. Warszawa: Wydawnictwo sic!

Baudrillard J. (2006). Społeczeństwo konsumpcyjne, jego mity i struktury, tłum. S. Królak. Warszawa: Wydawnictwo sic!

Baudrillard J. (2006). W cieniu milczącej większości albo kres sfery społecznej, tłum. S. Królak. Warszawa: Wydawnictwo sic!

Baudrillard J. (2007). Wymiana symboliczna i śmierć, tłum. S. Królak. Warszawa: Wydawnictwo sic!

Berg H. C. (1983). Freie Schulen als Regelschulen. W: Zeitschrift für Pädagogik zum 8. Kongreß der Deutschen Gesellschaft für Erziehungswissenschaft. WeiheimBasel: Beltz Verlag.

Carlgren F., Klingborg A. (2010). Wychowanie do wolności. Pedagogika Rudolfa Steinera. Obrazy i relacje z międzynarodowego ruchu szkół waldorfskich, tłum. M. Głażewski. Kraków: Oficyna Wydawnicza „Impuls”.

Dilthey W. (1987). O istocie filozofii i inne pisma, tłum. E. Paczkowska-Łagowska. Warszawa: PWN.

Encyclopaedia Britannica, hasło Education, dostępny na: http://www.britannica. com/EBchecked/topic/179408/education (otwarto: 12.12.2013). 
Folkierska A. Wychowanie w perspektywie hermeneutycznej. W: Kwieciński Z., Witkowski L. (red.). (1990). Ku pedagogii pogranicza. Toruń: Uniwersytet Mikołaja Kopernika, Ośrodek Studiów Kulturowych i Edukacyjnych.

Głażewski M. (1996). O witalności szkoły. Zielona Góra: Oficyna Wydawnicza WSP. Głażewski M. (2010). Dystopia. Pedagogiczne konteksty teorii systemów autopojetycznych Niklasa Luhmanna. Zielona Góra: Oficyna Wydawnicza Uniwersytetu Zielonogórskiego.

Gnitecki J. (1989a). Empiryczna koncepcja pedagogiki. Poznań: Wydawnictwo Naukowe PTP.

Gnitecki J. (1989b). Elementy metodologii badań w pedagogice hermeneutycznej. Poznań: Wydawnictwo Naukowe PTP.

Gnitecki J. (1989c). Metodologiczne problemy pedagogiki prakseologicznej. Poznań: Wydawnictwo Naukowe PTP.

Goethe J.W. (1967). Faust. Tragedii część pierwsza, tłum. W. Kościelski Warszawa: PIW.

Hartman J. (1997). Heurystyka filozoficzna. Wrocław: Wydawnictwo Leopoldinum Fundacji dla Uniwersytetu Wrocławskiego.

Hejnicka-Bezwińska T. (1990). Paradygmat pedagogiki instrumentalnej w Polsce. W: Kwieciński Z., Witkowski L. (red.). Ku pedagogii pogranicza. Toruń: Uniwersytet Mikołaja Kopernika, Ośrodek Studiów Kulturowych i Edukacyjnych. Hejnicka-Bezwińska T. (1995). Edukacja-kształcenie-pedagogika. Fenomen pewnego stereotypu. Kraków: Oficyna Wydawnicza „Impuls”.

Hessen S. (1973). Filozofia-Kultura-Wychowanie, wstęp: T. Nowacki, oprac. Hessenowa M. W: Hessen S.: „Źródła do dziejów myśli pedagogicznej”. T. XVII. Wrocław: Zakład Narodowy im. Ossolińskich - Wydawnictwo.

Kamiński W. (1996). Człowiek dorosły w sytuacjach zagrożenia tożsamości W: Wujek T. (red.). Wprowadzenie do andragogiki. Warszawa: Wydawnictwo Instytutu Technologii Eksploatacji.

Key E. (2005). Stulecie dziecka, tłum. R. Moszczyńska. Warszawa: Wydawnictwo Akademickie Żak.

Kmita J. (1982). Praktyka pedagogiczna i jej badanie w świetle teorii kultury. W: tenże (red.). Studia z teorii kultury i metodologii badań nad kultura. Warszawa: PWN.

Konarzewski K. (1982). Podstawy teorii oddziaływań wychowawczych. Warszawa: PWN

Kowalski S. (1979). Socjologia wychowania w zarysie. Warszawa: PIW.

Gwóźdź A., Hendrykowska M. (red.). (1995). Kronika filmu. Warszawa: wyd. Kronika - Marian B. Michalik.

Król M., Arendt H. (1991). Przedmowa. W: Arendt H. (1991). Myślenie, tłum. H. Buczyńska-Garewicz. Warszawa: Spółdzielnia Wydawnicza „Czytelnik”.

Kunowski S. (1993). Podstawy współczesnej pedagogiki. Warszawa: Wydawnictwo Salezjańskie. 
Kwieciński Z. (1982). Konieczność-niepokój-nadzieja. Problemy oświaty w latach siedemdziesiątych. Warszawa: Ludowa Spółdzielnia Wydawnicza.

Kwieciński Z. (Jabłonna, 15-17 grudnia 1988). Aporia edukacji wobec pęknięcia moralnego. Zarys problematyki. Referat na konferencje „Kultura jako czynnik rozwoju edukacji humanistycznej" (mps powielony).

Kwieciński Z. (8.17.1987). Wspólnota złudzeń reformatorów oświaty i ich ekspertów. W: Badania oświatowe i polityka oświatowa. Materiały na konferencje „Badania oświatowe”, w ramach CPBP. Jabłonna p. Warszawą: Polskie Towarzystwo Pedagogiczne, IRWIR PAN (mps powielony).

Kwieciński Z. (1990). Dynamika funkcjonowania szkoły. Warszawa: PWN.

Kwieciński Z. (2011). Co robić? W: Kwieciński Z. Dylematy. Inicjatywy. Przebudzenia. Wrocław: Wydawnictwo Naukowe DSW.

Kwieciński Z. (2012). Nowe nierówności społeczne w edukacji wyższej. W: tenże, Pedagogie postu. Preteksty-konteksty-podteksty. Kraków: Oficyna Wydawnicza "Impuls".

Lechte J. (1999). Panorama współczesnej myśli humanistycznej. Od strukturalizmu do postmodernizmu, tłum. T. Basznia. Warszawa: Książka i Wiedza.

Lichenberg G. C. (2005). Pochwała wątpienia. Bruliony i inne pisma, wybór, przekład, wstęp i przypisy: Zatorski T . Gdańsk: wyd. słowo/obraz/terytoria.

Łotman J. (2008). Uniwersum umysłu. Semiotyczna teoria kultury. Gdańsk: Wydawnictwo UG.

Łukaszewicz R. (1990). W poszukiwaniu alternatywy humanistycznej: od zaufania edukacji do zaufania człowiekowi. W: Alternatywna pedagogika humanistyczna. konferencja $w$ Jabłonnie $k$. Warszawy $w$ dniach 29 listopada - 1 grudnia 1984: Zbiór studiów, Suchodolski B. (red.). Wrocław: Ossolineum.

Markowski M. P. (2001). Słownik. W: Baudrillard J. Ameryka, tłum. R. Lis. Warszawa: Wydawnictwo sic!

Mead M. (200o). Kultura i tożsamość. Studium dystansu międzypokoleniowego, tłum. J. Hołówka. Warszawa: WN.

Mirski J. (1936). Wychowanie i wychowawca Warszawa: Nasza Księgarnia.

Muszyński H. (1976). Zarys teorii wychowania. Warszawa: PWN.

Mysłakowski Z. (1964). Wychowanie człowieka w zmiennej społeczności. Warszawa: Wydawnictwo Książka i Wiedza.

Obuchowski K. (Jabłonna 24-26 listopada 1987). Mikro- i makroświat człowieka, referat na konferencję naukowa "Strategia obrony i rozwoju cywilizacji humanistycznej" (mps powielony).

Okoń W. (1981). Słownik pedagogiczny. Warszawa: PWN.

Olszewska-Dyoniziak B. (200o). Zarys antropologii kulturowej. Zielona Góra: Zachodnie Centrum Organizacji.

Platon. Platon, Sofista. Polityk (1956), opr. Gromska D., tłum. W. Witwicki. Warszawa: PWN. 
Pratt T. We are Creating Walmarts of Higher Education, dostępny na: http://www. theatlantic.com/education/archive/2013/12/we-are-creating-walmarts-of-higher- education/282619 (otwarto: 12.12.2013).

Ritzer G. (2003). Makdonaldyzacja społeczeństwa, tłum. L. Stawowy. Warszawa: Warszawskie Wydawnictwo Literackie Muza SA.

Sawisz A. (1989). Szkoła a system społeczny. Warszawa: WSiP.

Schulz R. (1992). Szkoła-instytucja-system-rozwój. Toruń: Wydawnictwo Edytor.

Suchodolski B. (1981). Społeczeństwo istniejące i społeczeństwo pożądane, „Studia Filozoficzne" nr 7-8.

Suchodolski B. (1985). Kim jest człowiek? Warszawa: Wydawnictwo Wiedza Powszechna.

Szacki J. (1986). Znaniecki. Warszawa: Wydawnictwo Wiedza Powszechna.

Szołtysek A. E. (1986). Kontrowersje wokół arystotelesowskich kategorii paidagogike $i$ «politykon dzoon». "Studia Filozoficzne”, nr 7.

Witkowski L. (1988). Spór o edukacje jako spór o zmianę społeczną. W: Nowak J. (red.) Oświata $i$ wychowanie $w$ okresie cywilizacyjnego przełomu. Warszawa: Polskie Towarzystwo Pedagogiczne.

Znaniecki F. (1987). Znaczenie rozwoju świata i człowieka. W: tenże. „Myśl i rzeczywistość" i inne pisma filozoficzne. Warszawa: PWN.

Znaniecki F. (1964). Social Groups in the Modern World. W: Freedom and Control in Modern Society. New York: Octagon Book.

\title{
EDUCATION AS SIMULACRUM
}

\begin{abstract}
The paper refers to the notion of simulacrum, a term created by Jean Baudrillard in his work "Simulacra and Simulation", a philosophical treatise from 1981, in which he seeks to examine the relationships among reality, symbols, and society, in particular the significations and symbolism of culture and media that are involved in constructing an understanding of shared existence. Simulacra are copies that depict things which either had no original to begin with, or which no longer have an original. Simulation is the imitation of the operation of a real-world process or system over time. The aim of the article is to disassemble the semantic scope of the simulating function of education in the context of the question about the usefulness of Baudrillard's simulacrum metaphor as a heuristic tool for education analysis. The paper consists of four parts: 1 . Education - terminological clarification; 2. A question about the simulative function of education; 3. Simulacrum as a heuristic tool for education analysis; 4 . Education as simulacrum of a hypermarket.
\end{abstract}

Key words: education, pedagogics, simulacrum, reality, symbols, culture, hypermarket.

Michał Głażewski - dr hab., prof. nadzwyczajny Uniwersytetu Pedagogicznego im. KEN w Krakowie. Zajmuje się filozofią wychowania, pedagogiką ogólną, pedagogiką alternatywną. Najważniejsze publikacje: O witalności szkoły (Zielona Góra 1996), Dystopia. Pedagogiczne konteksty teorii systemów autopojetycznych Niklasa Luhmanna. (Zielona Góra 2010). Adres e-mailowy: michal.glazewski@up.krakow.pl. 